\title{
Aplikasi Edukasi Pengenalan Profesi Pemadam Kebakaran Berbasis Augmented Reality
}

\author{
Andhik Ampuh Yunanto ${ }^{1}$, Dina Ayu Fitriana ${ }^{2}$, Muhammad Fajar Mukhti ${ }^{3}$, Monica Kristania ${ }^{4}$, \\ Nadhif $^{5}$ \\ ${ }^{1}$ Departemen Teknik Informatika dan Komputer, Politeknik Elektronika Negeri Surabaya, \\ Jalan Raya ITS, Kampus PENS Sukolilo Surabaya, 60111 \\ e-mail: '1andhikyunanto@gmail.com, ${ }^{2}$ dinaayu13@it.student.ac.id, ${ }^{3}$ fajarmukti18@it.student.pens.ac.id, \\ ${ }^{4}$ monicakristania@it.student.pens.ac.id, ${ }^{5}$ nadhif@it.student.pens.ac.id
}

Submitted Date: August $16^{\text {th }}, 2020$

Revised Date: September $27^{\text {th }}, 2020$
Reviewed Date: September $22^{\text {nd }}, 2020$

Accepted Date: September $30^{\text {th }}, 2020$

\begin{abstract}
In this era, science and technology continue to develop significantly. One technology that is developing rapidly is information technology. This technological development can be used by the community and developers to help their work. One of the benefits of using this information technology is that it can help in the field of education. In addition, there are lots of cutting-edge technologies that are already sophisticated, namely Augmented Reality (AR) technology. In providing education to the younger generation, there are many insights that must be taught in addition to compulsory lessons in school. One of them is an insight into the use of internal fire extinguishers. Until now people tend to lack understanding of how this tool works because it is considered insignificant. Even though the fact is this is important to equip someone when one day there will be a fire. So that in this study proposes the development of an interactive learning application regarding fire extinguishers. This research has several stages including the identification of educational materials, the design and development of educational media, and testing of user convenience for early childhood where they are the target users of this application. This learning application built is a learning platform for children based on Augmented Reality. The test results show that this application gets positive feedback from child users where on average it gives a value of 9 . So it can be concluded that child users can learn how the firefighting profession works and children can immediately practice it interactively through this learning application.
\end{abstract}

Keywords: Learning Applications; Fire Extinguisher; Augmented Reality

\begin{abstract}
Abstrak
Di era ini, ilmu pengetahuan dan teknologi terus berkembang secara signifikan. Salah satu teknologi yang berkembang dengan pesat adalah teknologi infomasi. Perkembangan teknologi ini bisa dimaanfaatkan oleh para masyarakat dan developer dalam membantu pekerjaannya. Salah satu manfaat penggunaan teknologi informasi ini adalah dapat membantu dalam bidang pendidikan. Selain itu, banyak sekali teknologi mutakhir yang sudah canggih yakni teknologi Augmented Reality (AR). Dalam memberikan pendidikan kepada generasi muda, banyak sekali wawasan yang harus diajarkan selain pelajaran wajib di Sekolah. Salah satunya adalah wawasan mengenai tentang pemakaian alat pemadam api dalam. Hingga saat ini masyarakat cenderung kurang memahami mengenai cara kerja alat ini dikarenakan dirasa kurang berarti. Padahal faktanya hal ini penting untuk membekali seseorang ketika suatu saat akan terjadi kebakaran. Sehingga dalam penelitian ini mengusulkan pengembangan aplikasi pembelajran yang interaktif mengenai alat pemadam api. Penelitian ini memiliki beberapa tahapan diantaranya adalah identifikasi materi edukasi, perancangan dan pembangunan media edukasi, dan pengujian kemudahan pengguna kepada anak usia dini di mana mereka adalah target pengguna dari aplikasi ini. Aplikasi pembelajaran yang dibangun ini merupakan sebuah platform pembelajaran untuk anak berbasis Augmented Reality. Hasil pengujian menunjukkan bahwa aplikasi ini mendapat timbal balik yang positif dari pengguna anak-anak di mana rata-rata memberikan nilai 9. Sehingga dapat disimpulkan bahwa pengguna anak-anak dapat belajar
\end{abstract}


bagaimana profesi pemadam kebakaran berkerja dan anak-anak pun bisa langsung mempraktikan secara interaktif melalui aplikasi pembelajaran ini.

Kata Kunci: Aplikasi Pembelajaran; Pemadam Kebarakan; Augmented Reality

\section{Pendahuluan}

Kebakaran merupakan suatu kejadian atau peristiwa munculnya api yang tidak terkendali dan dapat membahayakan keselamatan jiwa maupun harta benda menurut Perda DKI No.3 tahun 1992. Sebagai salah satu kota dengan suhu yang tinggi yaitu mencapai 35 derajat celcius, Surabaya mempunyai potensi untuk terjadinya kebakaran.

Berdasarkan data yang diambil dari Badan Pusat Statistik Kota Surabaya, Jumlah kebakaran yang terjadi di Surabaya memiliki kecenderungan yang meningkat dari tahun 2011 hingga 2015 dengan 4 jenis objek yang terbakar, yaitu gedung, alang-alang, kendaraan, dan lain -lain. Kebakaran gedung merupakan kebakaran yang memiliki frekuensi terbesar dengan total jumlah 705 kejadian selama 2011 hingga 2015.

Simulasi penggunaan alat pemadam api secara langsung merupakan cara terbaik untuk memberikan edukasi tentang pemakaian alat pemadam api. Adapun kelebihan dari simulasi secara langsung adalah peserta mudah memahami materi yang diajarkan karena langsung melakukan praktek menggunakan alat pemadam api di lapangan serta peserta dapat bertan ya kepada pelatih bila ada ketidakpahaman. Namun disisi lain terdapat kekurangan dari simulasi kebakaran secara langsung, yaitu tingginya biaya yang dikeluarkan untuk menyelenggarakan simulasi kebakaran.

Pada perkembangan teknologi saat ini, banyak sekali media pembelajaran yang dapat digunakan dalam mendidik para pengguna (Yunanto \& Rochimah, 2017). Bebeapa diantaranya adalah dapat menggunakan media permainan (Yunanto, Herumurti, Kuswadayan, Hariadi, \& Rochimah, 2019). Tidak hanya itu, teknologi yang diterapkan saat ini juga memanfaatkan metode mutakhir seperti kecerdasan buatan (Yunanto, Herumurti, \& Kuswardayan, 2018) dan bahasa natural (Yunanto, Herumurti, Rochimah, \& Kuswardayan, 2019).

Salah satu alternatif yang dapat digunakan sebagai media pembelajaran cara pemakaian alat pemadam api adalah Augmented Reality. Augmented Reality atau disingkat dengan AR adalah suatu teknologi yang menggabungkan objek virtual dengan benda nyata yang ada di sekitar dalam waktu yang sebenarnya. Dengan kata lain,
AR ini dapat membuat pengguna merasakan kehadiran objek-objek virtual di dunia secara asli. Tidak hanya itu, Teknologi AR juga sering dimanfaatkan di berbagai bidang seperti bidan robotika (Pace, Manuri, Sanna, \& Fornaro, 2020), tempat bersejarah (Kaghat, Azough, Fakhour, \& Meknassi, 2020), bidang kesehatan (NegrilloCárdenas, Juan-Roberto, Jiménez-Pérez, \& R.Feito, 2020), dan bidang pendidikan (Kaur, Mantri, \& Horan, 2020).

Di dunia pendidikan saat ini, teknologi AR juga telah digunakan sebagai alternatif pembelajaran materi baik di sekolah maupun di perguruan tinggi. Beberapa faktor alasan teknonogi AR ini digunakan dalam dunia pendidikan diantaranya adalah proses dan sistem kerjanya sangat sederhana, efektif, efisien, dan interaktif (Yim, Chu, \& L.Sauer, 2017). Selain itu, teknologi AR ini juga berpotensi digunakan untuk pelatihan bidang lain. Alasan tersebut terjadi karena dengan memanfaatkan teknologi AR, suatu proses dan sistem pembelajaran akan lebih aman dan nyaman untuk dilakukan dalam mengingat objek yang akan digunakan di dunia virtual (Herumurti, Yuniarti, Rimawan, \& Yunanto, 2019).

Dengan demikian, Aplikasi Edukasi Pengenalan Profesi Pemadam Kebakaran Berbasis Augmented Reality menjadi pilihan yang cukup menjanjikan untuk memberikan pemahaman bagi anak tentang cara pemakaian alat pemadam api. Dengan memakai media virtual ini, keuntungan yang akan didapat diantaranya lebih murah, menarik, mudah, dan aman bila dibandingkan dengan pembelajaran alat pemadam api secara langsung.

\section{Metode Penelitian \\ 2.1 Persiapan Kegiatan}

Persiapan kegiatan merupakan tahap awal di dalam metode penelitian ini. Beberapa persiapan kegiatan yang telah dilakukan meliputi:
a) Mendiskusikan lokasi tempat mitra.
b) Melakukan survei lokasi mitra.
c) Menghitung estimasi biaya yang dibutuhkan.

\subsection{Pengadaan dan Perlengkapan Kebutuhan.}

Tahap pengadaan ini merupakan tahap lanjutan setelah tahap persiapan kegiatan terlaksana. Terdapat beberapa hal yang dilakukan pada tahap 
ini yakni berupa penyiapan alat serta perlengkapan kebutuhan untuk menunjang kesiapan proses pembuatan. Tahap ini juga membutuhkan kesiapan dalam hal biaya dan waktu dalam menentukan perlengkapan yang sesuai kebutuhan penelitian.

\subsection{Persiapan Produksi}

Selanjutnya adalah tahap persiapan produksi di mana dilakukan setelah persiapan sebelumnya telah selesai. Persiapan produksi ini artinya mempersiapkan teknologi dan data pendukung dalam pembuatan aplikasi pembelajaran. Beberapa yang dilakukan dalam tahap ini meliputi:

a) Menyiapkan tempat produksi yang kondusif

b) Melakukan Riset dan mempelajari teknologi yang digunakan dalam pengembangan.

\subsection{Perancangan Sistem}

\subsubsection{Usecase Diagram}

Pembuatan Usecase diagram merupakan langkah awal dalam melakukan perancangan sistem yang dibangun. Usecase diagram yang ditunjukkan pada Gambar 1 terlihat bahwa user memiliki peran sebagai client side. Artinya pengguna dapat membuka aplikasi dan dapat mempelajari tentang cara pemakaian alat pemadam api secara langsung dengan menggunakan teknologi Augmented Reality.

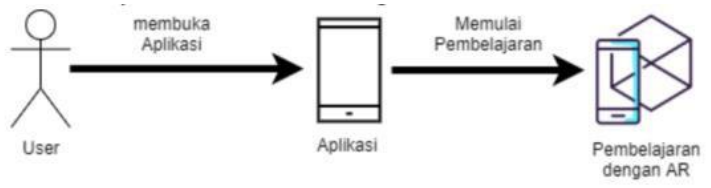

Gambar 1. Usecase Diagram

\subsubsection{Flowchart}

Perancangan selanjutnya adalah membuat rancangan Flowchart. Pada Gambar 2 dapat dilihat Flowchart atau alur dari aplikasi pembelajaran yang dikembangkan.

\subsubsection{Diagram Aktivitas Memadamkan Api}

Perancangan diagram aktivitas digunakan untuk mengetahuk alur aktivitas yang seperti apa yang diterapkan pada sistem. Pada Gambar 3 dapat dilihat alur proses aktivitas pengguna dimulai dari menekan tombol hingga selesai.

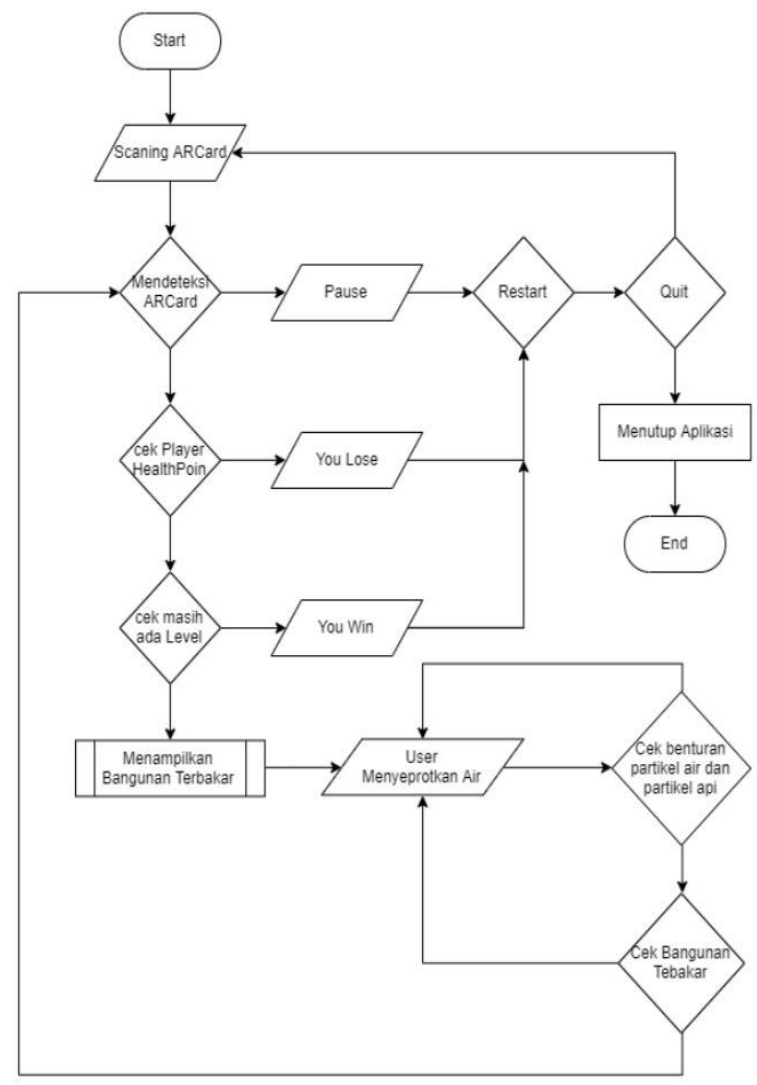

Gambar 2. Flowchart

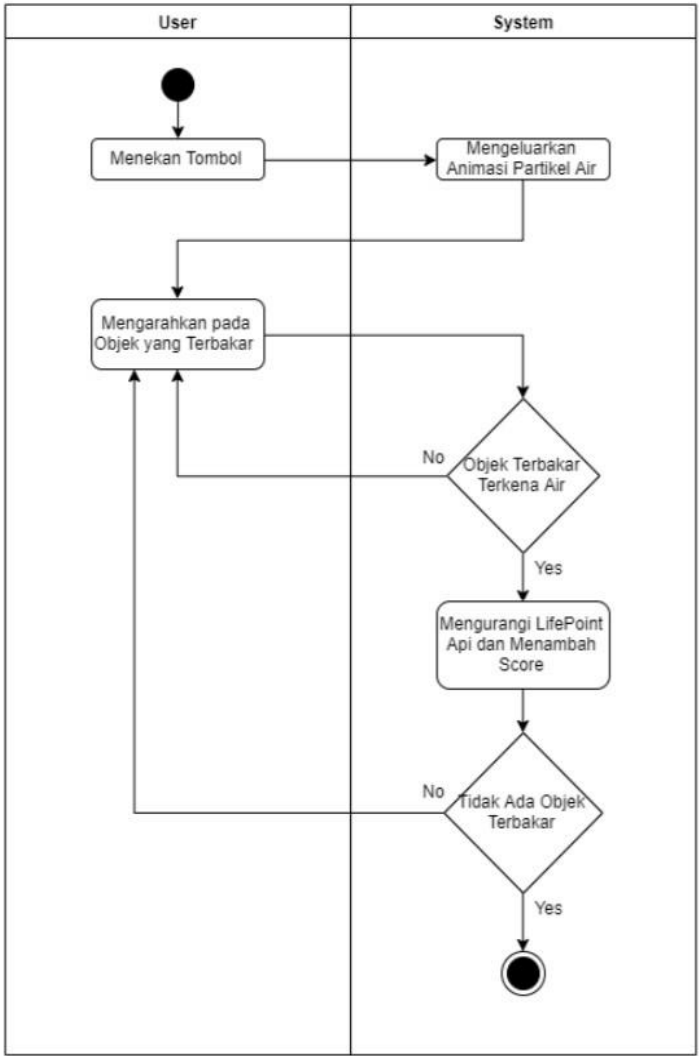

Gambar 3. Diagram Aktivitas Memadamkan Api 


\subsubsection{Diagram Activity Memulai Ulang}

Selanjutnya, dilakukan perancangan untuk diagram aktivitas lain yakni aktivitas memulai ulang. Pada Gambar 4 dapat dilihat diagram aktivitasnya di mana pengguna dapat memulai kembali skenarionya dari awal.

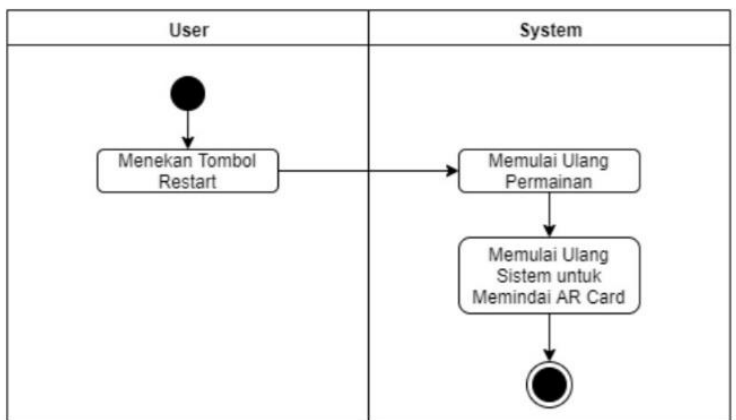

Gambar 4. Diagram Aktivitas Memulai Ulang Pembelajaran

\subsubsection{Diagram Activity Menutup Aplikasi}

Diagram aktivitas selanjutnya adalah aktivitas untuk menuput aplikasi. Gambar 5 menunjukkan diagram aktivitas dalam menutup aplikasi pembelajaran yang dikembangkan ini.

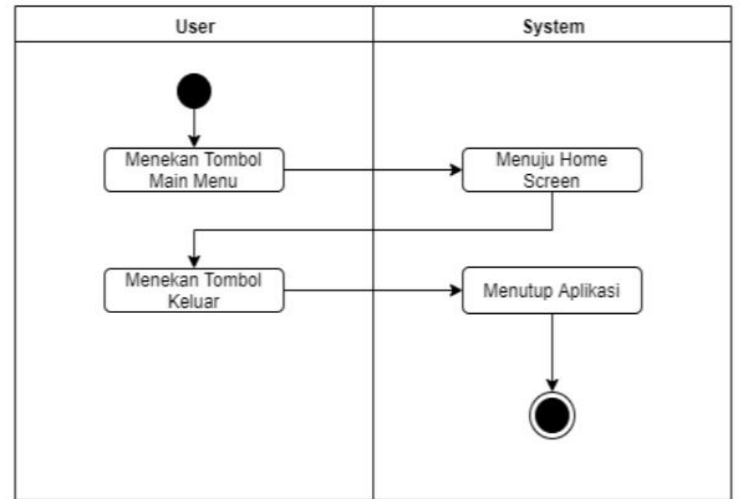

Gambar 5. Diagram Aktivitas Menutup Aplikasi

\subsubsection{Squance Diagram}

Sequence diagram atau diagram sekuensial merupakan diagram untuk menunjukkan alur teknik dari sistem yang yang dibangun. Pada Gambar 6 terlihat bahwa sistem berjalan dimulai dari pengguna saat melakukan scanning menggunakan teknologi AR dan berakhir ketika pengguna menutup atau memulai ulang aplikasi.

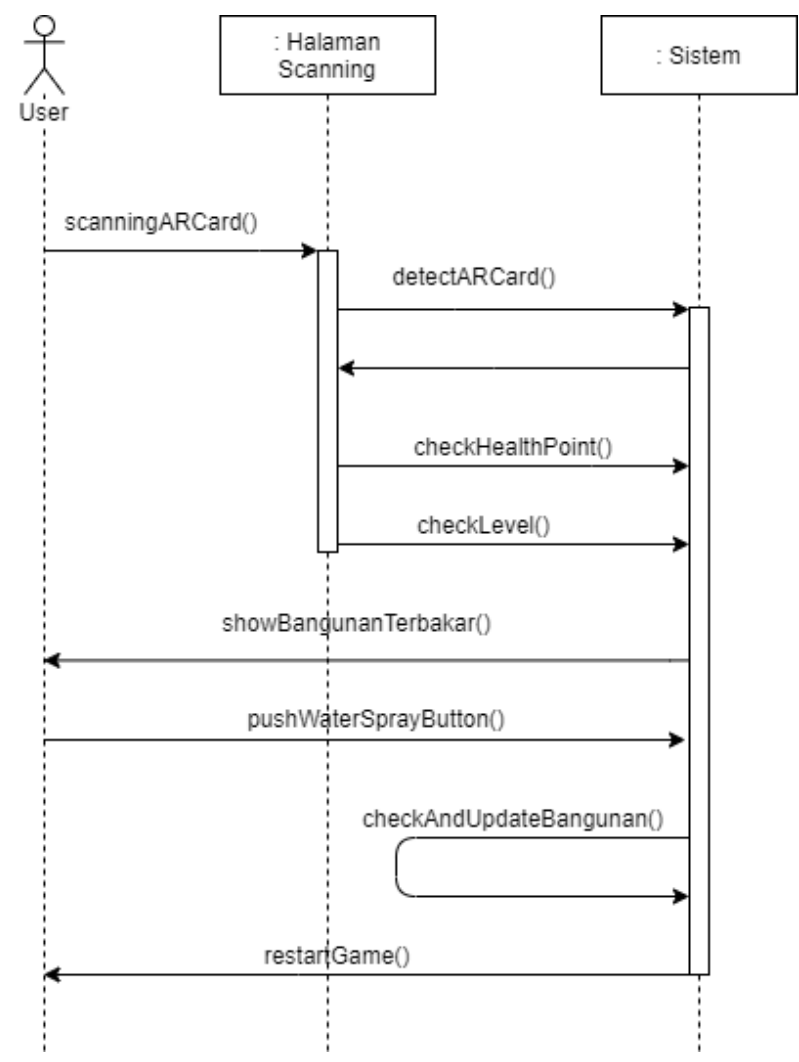

Gambar 6. Diagram Sekuensial pada Sistem

\subsubsection{Mockup}

Bagian ini merupakan tampilan dari halaman yang dapat diakses oleh user, antara lain adalah halaman untuk memulai pembelajaran pemadaman kebakaran, halaman paused, halaman untuk menampilkan score, dan yang terakhir adalah halaman pembelajaran yang berbasis Augmented Reality.

\subsection{Implementasi Sistem}

Tahap implementasi dilakukan setelah tahap perancangan sistem telah selesai. Tahap implementasi ini melakukan pengembangan dalam sisi teknik seperti coding dan debugging. Sistem dibangun dengan menggunakan IDE Unity dan memanfaatkan library AR yang dinamakan Vuvoria.

\subsection{Uji Coba SIstem}

Setelah implementasi selesai, tahap selanjutnya adalah tahap pengujian untuk mengetahui apakah aplikasi telah berjalan sebagaimana mestinya. Terdapat dua pengujian dalam penelitian ini diantaranya adalah pengujian performa sistem dan pengujian pengguna. 


\subsection{Perbaikan Hasil Produk}

Setelah dilakukan pengujian, maka akan dilakukan tahap perbaikan dan pengembangan kembali. Tahap ini dilakukan supaya aplikasi yang dibangun menjadi lebih baik dan lebih sempurna khususnya di penelitian selanjutnya.

\subsection{Penyusunan Laporan}

Tahap terakhir dari kegiatan ini adalah penyusunan laporan dari setiap analisa kegiatan dan tahapan yang telah dilaksanakan. Pada Gambar 7 berikut ini merupakan alur tahapan pelaksanaan penelitian secara umum.

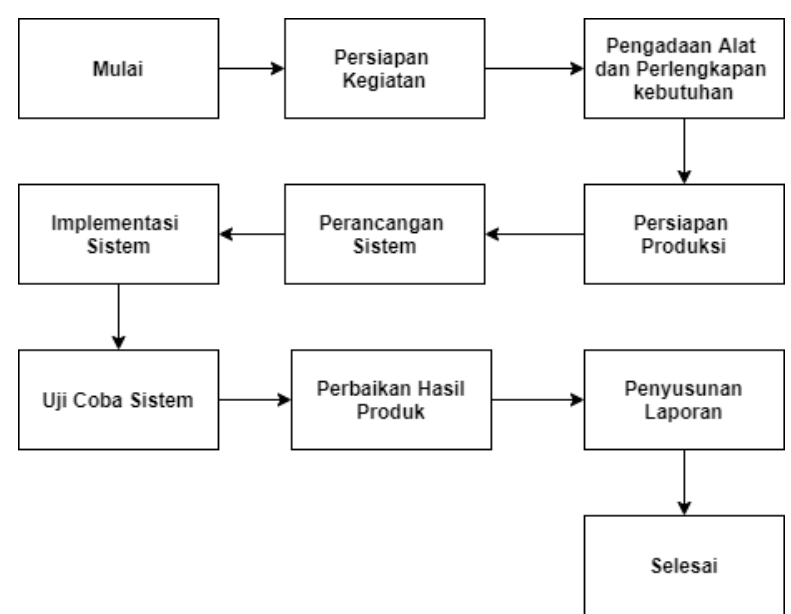

Gambar 7. Alur Pelaksanaan.

\section{Hasil dan Pembahasan}

\subsection{Splash Screen}

Halaman ini muncul ketika aplikasi pertama kali dibuka. Halaman ini menampilkan icon unity karena menggunakan tools unity dalam pembuatan aplikasi ini. Tampilan ditunjukkan pada Gambar 8.

\subsection{Scan Marker}

Setelah tampilan splash screen, untuk memulai permainan ini pengguna diminta untuk mengarahkan kamera ke marker AR. Marker ini akan menghasilkan output AR. Tampilan ditunjukkan pada Gambar 9.

\subsection{Persiapan}

Bila marker berhasil terdeteksi, maka akan menampilkan animasi Gedung terbakar dan hitungan mundur yang menandakan permainan akan dimulai. Pada tahap ini alat pemadam masih belum mengeluarkan air, ditunjukkan pada Gambar 10.

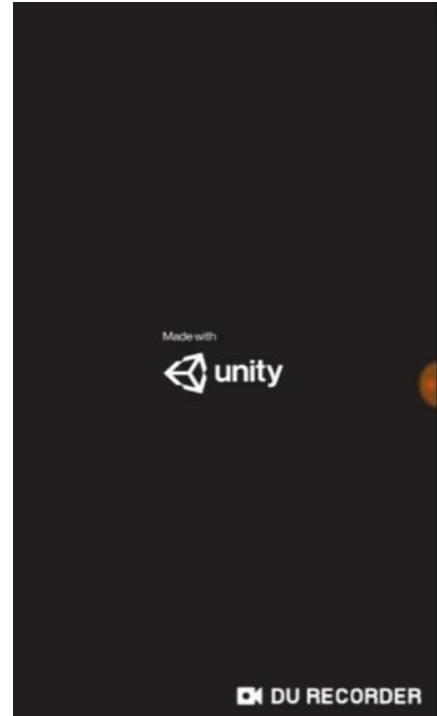

Gambar 8. Splash Screen

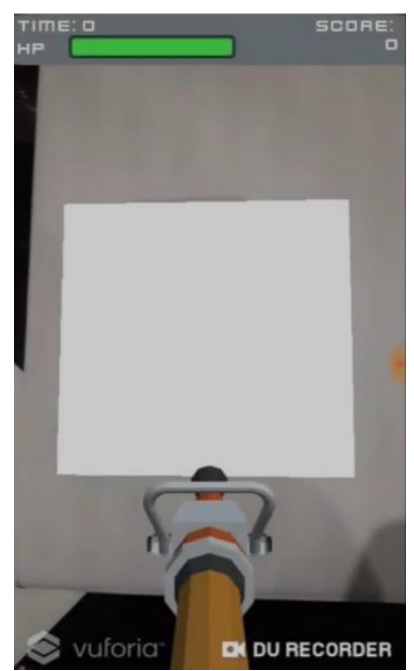

Gambar 9. Scan Marker

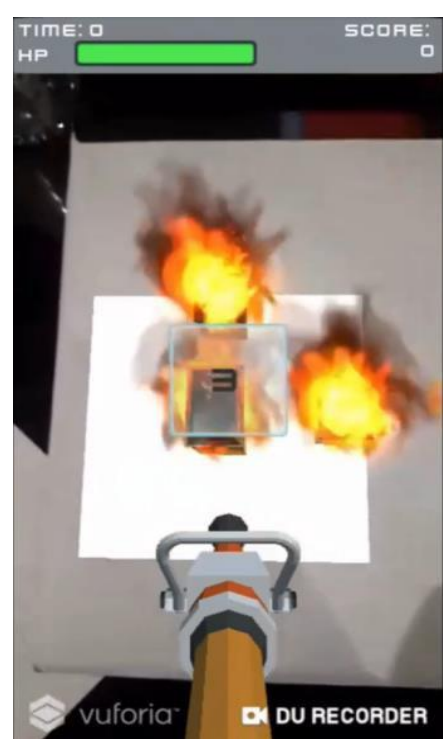

Gambar 10. Persiapan 


\subsection{Permainan dimulai}

Setelah hitung mundur selesai, pengguna dapat melakukan simulasi pemadaman kebakaran dengan mengarahkan selang air ke bangunan yang terbakar hingga api padam. Selain terdapat animasi api, asap, dan air, juga terdapat suara bangunan yang terbakar dan suara sirine mobil pemadam kebakaran sehingga semakin terlihat lebih nyata. Permainan ini dimulai dengan wave satu hingga wave empat. Indikator time akan terus berjalan selama permainan ini dimulai. Score akan bertambah jika pengguna berhasil memadamkan api pada gedung yang terbakar. HP atau heath point mengindikasikan kesehatan pengguna, bila gedung tidak segera disiram maka HP akan berkurang, jika HP sudah habis maka pengguna akan kalah.

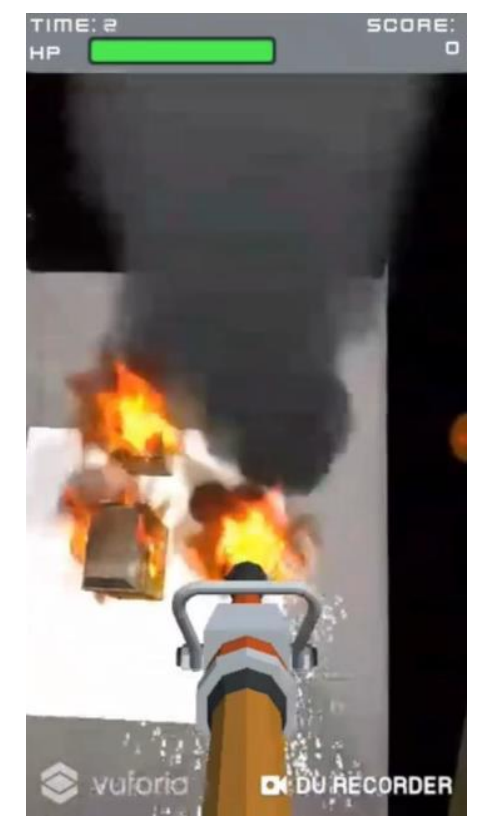

Gambar 11. Permainan dimulai

\subsection{Resume Permainan}

Ketika kamera smartphone pengguna tidak mengarah ke marker, maka permainan akan otomatis terpause. Pop up pause akan keluar yang berisi petunjuk untuk mengarahkan kamera ke marker untuk melanjutkan permainan. Selain itu juga terdapat tombol restart bila pengguna ingin mengulang permainan dan tombol quit bila ingin keluar dari permainan.

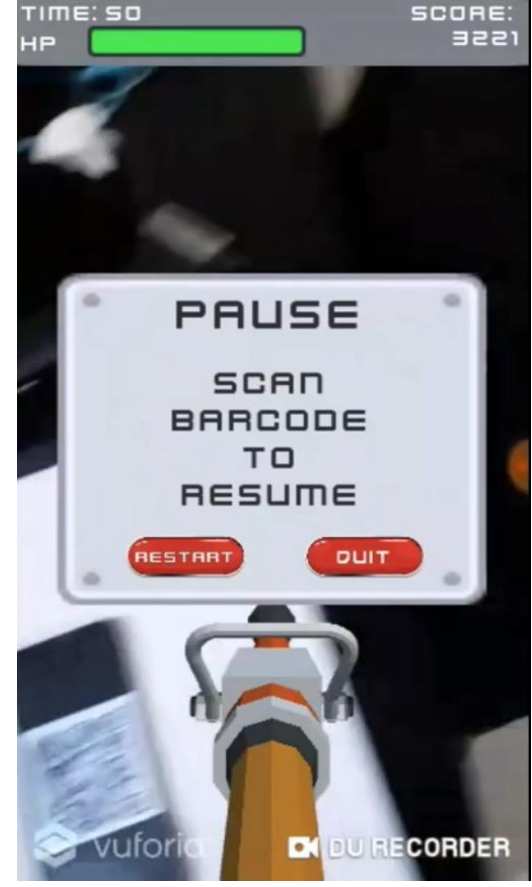

Gambar 12. Resume Permainan

\subsection{Permainan Selesai}

Pengguna yang berhasil menyeselaikan permainan hingga wave empat maka akan muncul pop up kemenangan. Pop up akan menampilkan total score dan waktu yang dihabiskan untuk memenangkan permainan ini. Selain itu juga terdapat tombol restart untuk mengulangi permainan dan tombol quit untuk keluar dari permainan.

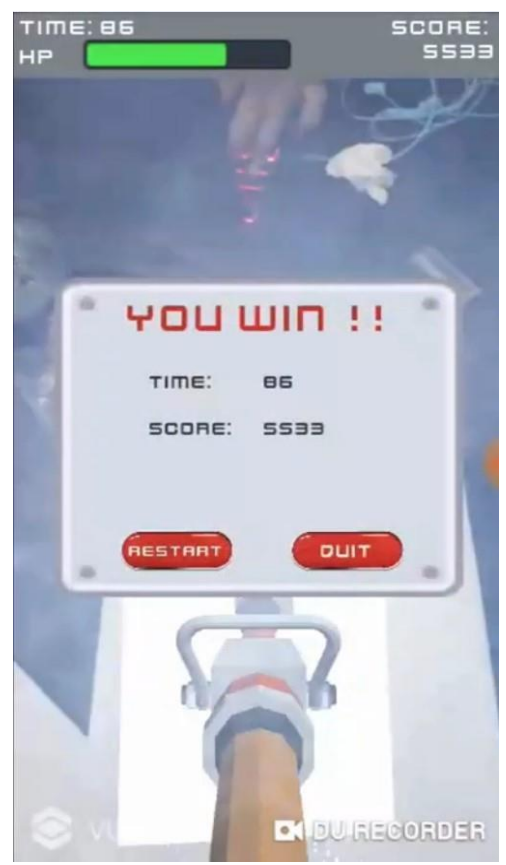

Gambar 13. Permainan selesai 


\subsection{Pengujian}

Pengujian dilakukan dengan cara mencobakan aplikasi ke anak sekolah dasar. Uji coba dilakukan kepada beberapa anak sekolah dasar dengan cara memberikan tutorial dan diminta memainkannya langsung. Setelah mencoba aplikasi tersebut, user diberi beberapa pertanyaan secara langsung terkait aplikasi pembelajaran tersebut. Pertanyaan yang diberikan antara lain seperti tanggapan mengenai aplikasi tersebut di mana memiliki nilai antara 1 sampai dengan 10 .

\subsection{Hasil Feedback User}

Setelah melakukan uji coba, user berpendapat bahwa aplikasi ini cukup menarik karena AR nya namun karena harus mengarahkan kamera ke marker atau QR code membuat user merasa aplikasi ini terlalu ribet. Selain itu juga dari sisi suara juga menambah keseruan saat menggunakan aplikasi ini. Dari range 1 sampai 10 , rata-rata pengguna anak-anak memberikan nilai 9 untuk pengembangan aplikasi ini.

\subsection{Pembahasan}

Aplikasi ini dapat berjalan sebagaimana mestinya. Suara dan animasi AR berjalan dengan dengan baik membuat simulasi tampak lebih nyata. Namun terdapat sedikit bug bila aplikasi ini dijalankan pada smartphone tertentu. Bug ini berupa tidak keluarnya sebagian UI aplikasi.

\section{Kesimpulan}

Teknologi Augmented Reality pada aplikasi ini menarik bagi anak sekolah dasar yang mncobanya. Pengenalan profesi pemadam kebakaranpun menjadi lebih menyenangkan bagi user. Suara dan animasi yang dihasilkan juga menambah kesan nyata aplikasi ini.

\section{Future Work}

Harapan kedepannya teknologi AR pada aplikasi ini akan dikembangkan lagi menjadi Markerless Augmented Reality. Sehingga user dapat menggunakan aplikasi ini tanpa ribet akibat penggunaan bantuan marker.

\section{References}

Herumurti, D., Yuniarti, A., Rimawan, P., \& Yunanto, A. A. (2019). Overcoming Glossophobia Based on Virtual Reality and Heart Rate Sensors. IEEE International Conference on Industry 4.0, Artificial Intelligence, and Communications Technology (IAICT). Bali Indonesia.

Kaghat, F. Z., Azough, A., Fakhour, M., \& Meknassi, M. (2020). A new audio augmented reality interaction and adaptation model for museum visits. Computers \& Electrical Engineering.

Kaur, D. P., Mantri, A., \& Horan, B. (2020). Enhancing Student Motivation with use of Augmented Reality for Interactive Learning in Engineering Education. Procedia Computer Science, 881885.

Negrillo-Cárdenas, J., Juan-Roberto, Jiménez-Pérez, \& R.Feito, F. (2020). The role of virtual and augmented reality in orthopedic trauma surgery: From diagnosis to rehabilitation. Computer Methods and Programs in Biomedicine.

Pace, F. D., Manuri, F., Sanna, A., \& Fornaro, C. (2020). A systematic review of Augmented Reality interfaces for collaborative industrial robots. Computers \& Industrial Engineering.

Yim, M. Y.-C., Chu, S.-C., \& L.Sauer, P. (2017). Is Augmented Reality Technology an Effective Tool for E-commerce? An Interactivity and Vividness Perspective. Journal of Interactive Marketing, 89-103.

Yunanto, A. A., \& Rochimah, S. (2017). Systematic Literature Review Terhadap Evaluasi Perangkat Lunak Tentang Serious Game. Jurnal Informatika.

Yunanto, A. A., Herumurti, D., \& Kuswardayan, I. (2018). Kecerdasan Buatan Pada Game Edukasi Untuk Pembelajaran Bahasa Inggris Berbasis Pendekatan Heuristik Similaritas. Jurnal Sistem dan Informatika (JSI).

Yunanto, A. A., Herumurti, D., Kuswadayan, I., Hariadi, R. R., \& Rochimah, S. (2019). Design and Implementation of Educational Game to Improve Arithmetic Abilities for Children. 12th International Conference on Information \& Communication Technology and System (ICTS). Surabaya, Indonesia.

Yunanto, A. A., Herumurti, D., Rochimah, S., \& Kuswardayan, I. (2019). English Education Game using Non-Player Character Based on Natural Language Processing. The Fifth Information Systems International Conference. Surabaya, Indonesia. 